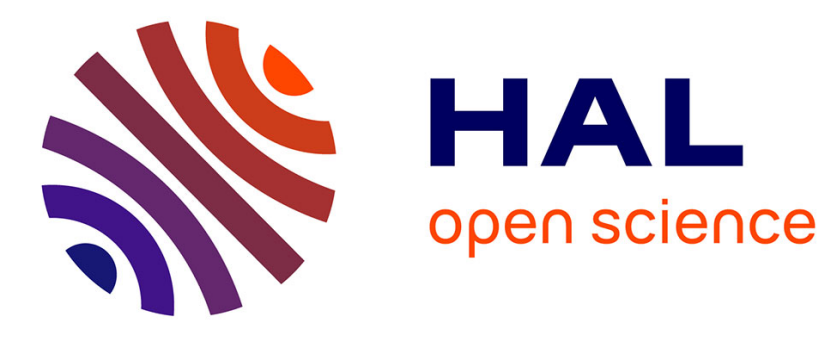

\title{
Aftershock sequence of the 1994, Mw 6.8, Liwa earthquake (Indonesia): seismic rupture process in a volcanic arc
}

Christina Widiwijayanti, Jacques Déverchère, Rémy Louat, Michel Sébrier, Hery Harjono, Michel Diament, Dannie Hidayat

\section{To cite this version:}

Christina Widiwijayanti, Jacques Déverchère, Rémy Louat, Michel Sébrier, Hery Harjono, et al.. Aftershock sequence of the 1994, Mw 6.8, Liwa earthquake (Indonesia): seismic rupture process in a volcanic arc. Geophysical Research Letters, 1996, 23, 21, pp.3051-3054. 10.1029/96GL02048 . insu-01356400

\section{HAL Id: insu-01356400 \\ https://hal-insu.archives-ouvertes.fr/insu-01356400}

Submitted on 25 Aug 2016

HAL is a multi-disciplinary open access archive for the deposit and dissemination of scientific research documents, whether they are published or not. The documents may come from teaching and research institutions in France or abroad, or from public or private research centers.
L'archive ouverte pluridisciplinaire HAL, est destinée au dépôt et à la diffusion de documents scientifiques de niveau recherche, publiés ou non, émanant des établissements d'enseignement et de recherche français ou étrangers, des laboratoires publics ou privés. 


\title{
Aftershock sequence of the 1994, Mw 6.8, Liwa earthquake (Indonesia): Seismic rupture process in a volcanic arc
}

\author{
Christina Widiwijayanti ${ }^{1,2}$, Jacques Déverchère ${ }^{3}$, Rémy Louat ${ }^{2,4}$, Michel Sébrier ${ }^{5}$, \\ Hery Harjono ${ }^{1}$, Michel Diament ${ }^{4}$, and Dannie Hidayat ${ }^{1}$
}

\begin{abstract}
We present the aftershock activity following the February 15, 1994, Mw 6.8 earthquake which was strongly felt in southern Sumatra, Indonesia, near the Great Sumatran Fault (GSF). At this place, the slip rate is supposed to be low; neverthless, three $M>6$ events occurred along this segment during this century. No significant instrumental microseismicity has ever been recorded there. We use data from both the regional Indonesian network and a local seismic array operating 11 days after the mainshock during one month. Aftershocks mostly locate in a broad zone of $55 \times 20 \mathrm{~km}^{2}$ near two active NW-trending strike-slip segments of the GSF separated by a recent caldera, Suwoh. During the experiment, the NW segment (from Suwoh up to $15 \mathrm{~km}$ SE of the Ranau lake caldera, an old right-stepover pull-apart) was very active. As first suggested by the aftershock distribution and the lack of coseismic rupture at the surface, the 20 focal mechanisms determined provide evidence for various post-seismic stress adjustments on secondary faults located in the Ranau-Suwoh paleo-pull-apart graben. Less than $20 \%$ of the aftershocks are directly linked to the main rupture, a nearly pure right-lateral strike-slip faulting reaching $25 \mathrm{~km}$ depth. A narrow seismic gap underlines the active volcanic area of Suwoh. We conclude that the rupture process along the GSF is controlled both by volcanism and structures, and that the volcanic activity affects the mechanical properties of the crust only in a narrow zone.
\end{abstract}

\section{Introduction}

A destructive earthquake devastated the region around the city of Liwa in southern Sumatra, Indonesia, on February 15, 1994 , at $17 \mathrm{~h} 08 \mathrm{mn}$ U.T. The mainshock was located at $5.24^{\circ} \mathrm{S}$, $104.56^{\circ} \mathrm{E}$ according to the Euro-Mediterranean Seismological Center (CSEM), at $5.4^{\circ} \mathrm{S}, 104.8^{\circ} \mathrm{E}$ by the U.S. National Earthquake Information Center (NEIC), and at $5.10^{\circ} \mathrm{S}$, $104.13^{\circ} \mathrm{E}$, using 16 regional stations of the Indonesian network. Magnitude estimates are $M w=6.8$ (Harvard, CMTS), $\mathrm{M}_{\mathrm{s}}=7.2$ (NEIC-USGS), and $\mathrm{m}_{b}=6.8$ (CSEM). The location from the USGS $\left(4.97^{\circ} \mathrm{S}, 104.30^{\circ} \mathrm{E}\right)$ [Seismological Notes, 1994] is close to the regional determination and provides a focal depth of $23 \mathrm{~km}$ from broadband seismograms. All determinations led to the conclusion that this event is shallow and occurred near the "Great Sumatran Fault" (GSF), a 1700 km-long crustalscale strike-slip fault system [Fitch, 1972]. More than 200 people died during the earthquake, and more than 2000 were injured. Extensive damage has been confined to a long, narrow zone near Liwa city, coinciding with the NW-SE strike of the

\footnotetext{
${ }^{1}$ Puslitbang Geoteknologi LIPI, Bandung, Indonesia.

${ }^{2}$ ORSTOM, Paris, France.

${ }^{3}$ UMR Géosciences Azur, Villefranche-sur-Mer, France.

${ }^{4}$ Institut de Physique du Globe, Paris, France.

${ }^{5}$ CNRS-URA 1369, Université de Paris-Sud, Orsay, France.
}

\section{Copyright 1996 by the American Geophysical Union}

GSF. This was the largest earthquake recorded in southern Sumatra since June $25,1933\left(5.09^{\circ} \mathrm{S}, 104.70^{\circ} \mathrm{E}, \mathrm{Ms}=7.5\right)$, which also displays a clear link with the GSF and affected roughly the same epicentral area [Berlage, 1934; Katili and Hehuwat, 1967]. Although events within the Sumatra island are less numerous and smaller than the fore-arc events, they may produce destructive effects due to their proximity to housing, and provide clues on the mechanics of faulting of major strike-slip systems [Mount and Suppe, 1992]. The 1994 Liwa earthquake was thus the first opportunity since the development of temporal and permanent networks to study the aftershock sequence of a large earthquake associated with the GSF. Furthermore, the GSF is located along the Sumatra volcanic arc: the aftershock sequence can thus provide some insights into the seismogenic behavior of the crust in a hot, volcanic area. A French-Indonesian team of seismologists organized a field experiment in the source region to observe possible fault displacements at the surface and to record and analyze the aftershock activity from February 28 to March 30 , 1994. We present here the aftershock distribution, fault plane solutions, and the deduced stress field. We discuss the results in the light of historical seismicity, surface observations before and after the Liwa earthquake [Bellier and Sébrier, 1994; Duquesnoy et al., this issue], and available kinematic data.

\section{Historic and Instrumental Seismicity}

The majority of large earthquakes in both historic and instrumental catalogs of the Sunda Arc locate in the fore-arc of Sumatra, and especially off SW Sumatra [Newcomb and McCann, 1987; Harjono et al., 1991]. The worldwide seismicity catalog (USGS) shows that from 1960 to 1995, earthquakes of magnitude 5 and more are clustering offshore, between Mentawai archipelago and south of Enggano islands, whereas activity on land is much less (Figure 1). This high level activity is probably not only related to the oblique convergence process of the Indian Plate below Eurasia, but also to the fore-arc deformation [Diament et al., 1992; Zen Jr., 1993]. Nevertheless, three large earthquakes $(M>6)$ have occurred since 1928 along and in the vicinity of the southern part of the GSF, a $100 \mathrm{~km}$-long right-stepover fault system also known as the Ranau-Suwoh-Semangka fault zone [Bellier and Sébrier, 1994]. The largest event is the $1933 \mathrm{Ms}=7.5$ earthquake near Liwa, which caused heavy damage in the Ranau-Suwoh area [Berlage, 1934]. No $M>6$ earthquake has occurred between 1933 and 1994 in the area. Temporary seismological studies have been previously conducted by FrenchIndonesian teams in southern Sumatra: one around the Sunda Strait [Harjono et al., 1991]; another covering the subduction zone, the southernmost part of GSF and the Mentawai fault zone by the use of marine and land stations [Zen Jr., 1993]. Both studies observed a low level of microseismicity in the southern part of the GSF, where slip rate is about $6 \pm 4 \mathrm{~mm} / \mathrm{yr}$, i.e. the lowest along the GSF [Bellier and Sébrier, 1995].

\section{Fieldwork}

Careful field observation revealed no surface rupture. Topography in the Liwa area is uneven, the weathering layer is 


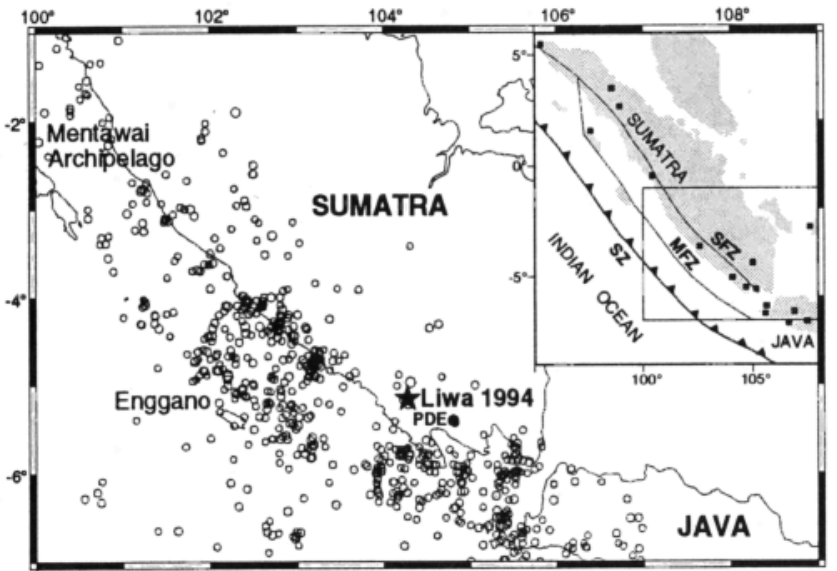

Figure 1. Shallow seismicity $(<60 \mathrm{~km})$ located by the worldwide USGS network from 1960 to $1995(M>5)$ in southern Sumatra, Indonesia. Solid circle and star are the PDE (Preliminary Determination of Epicentres, NEIC) and the Harvard location of the February 15, 1994, Liwa earthquake, respectively. Inset shows the position of the area, near the subduction (SZ) of the Indian plate below Eurasia (thick line). Thin lines are the Mentawai (MFZ) and Sumatran (SFZ) fault zones. Solid squares are permanent seismic stations.

thick, and consequently, many landslides were triggered by the mainshock. In addition, intense smoke and gas activity was observed in the Suwoh volcanic area (Figure 2). During the 11 days following the mainshock, the nine closest seismological stations of the permanent regional network of the Meteorological and Geophysical Agency (BMG) of Indonesia and one temporal station in Liwa provided only a rough estimate of the aftershock activity (inset on Figure 2), as most stations were too far from the rupture area (inset on Figure 1). From February 27 to March 28, we operated 12 portable seismographs with $1-\mathrm{Hz}$ vertical seismometers $(9$ analog and 3 digital instruments, Figure 2). Data from the five closest permanent stations from BMG network were added (Table). Despite difficulties of field access (many mudslides cut the roads after the earthquake and rains were heavy), the distribution of stations allows a good estimate of the aftershock locations from Ranau lake to Semangka bay. All instruments were located by GPS receivers and yielded arrival time accuracy

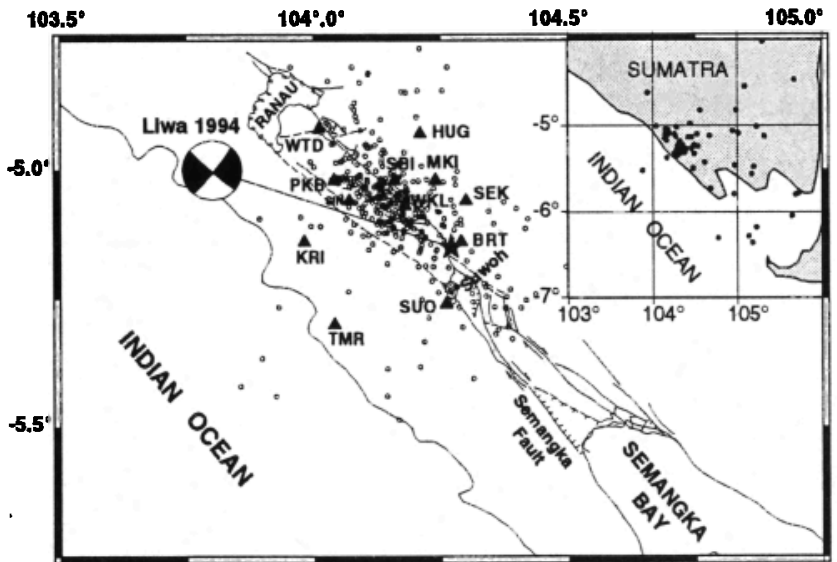

Figure 2. Aftershock distribution from February 15 to March 28, 1994, and temporal seismological network installed in March. Solid (inset) and open circles depict events located before and after February 28, 1994, respectively. Star is the CMT location of the mainshock after Harvard Univ., with the preferred Moment Tensor solution [Seismological Notes, 1994]. Continuous and dashed thin lines are major active and inactive fault traces of the GSF, respectively, after Bellier and Sébrier [1994]. Triangles are local stations.
Table. Seismological Network Used for Locations, and FourLayer Velocity Model Determined. Periods 1, 2, 3, and 4 are About: 02/17-03/30, 02/26-03/30, 03/01-03/16, and 03/1003/30, respectively. Regional Stations are Underlined.

\begin{tabular}{|c|c|c|c|c|}
\hline Station & Latitude S & Longitude E & Height, m & Period \\
\hline$\overline{\mathrm{PAS}}$ & $06^{\circ} 41.37^{\prime}$ & $105^{\circ} 35.33^{\prime}$ & 200 & 1 \\
\hline PUL & $06^{\circ} 20.70^{\prime}$ & $105^{\circ} 58.53^{\prime}$ & 1345 & 1 \\
\hline$\overline{\mathbf{K S I}}$ & $03^{\circ} 38.03^{\prime}$ & $102^{\circ} 35.54^{\prime}$ & 515 & 1 \\
\hline PEN & $05^{\circ} 34.00^{\prime}$ & $105^{\circ} 10.27^{\prime}$ & 200 & 1 \\
\hline $\mathrm{KL}$ & $05^{\circ} 51.00^{\prime}$ & $104^{\circ} 52.80^{\prime}$ & 38 & 1 \\
\hline SUO & $05^{\circ} 15.84^{\prime}$ & $104^{\circ} 15.81^{\prime}$ & 235 & 2 \\
\hline KRI & $05^{\circ} 08.37^{\prime}$ & $103^{\circ} 58.62^{\prime}$ & 200 & 2 \\
\hline SEK & $05^{\circ} 03.66^{\prime}$ & $104^{\circ} 17.72^{\prime}$ & 1350 & 2 \\
\hline WKL & $05^{\circ} 04.18^{\prime}$ & $104^{\circ} 10.89^{\prime}$ & 1000 & 2 \\
\hline SBI & $05^{\circ} 01.40^{\prime}$ & $104^{\circ} 09.57^{\prime}$ & 790 & 2 \\
\hline PKB & $05^{\circ} 01.03^{\prime}$ & $104^{\circ} 02.38^{\prime}$ & 970 & 2 \\
\hline WID & $04^{\circ} 55.15^{\prime}$ & $104^{\circ} 00.84^{\prime}$ & 610 & 2 \\
\hline MKI & $05^{\circ} 01.19^{\prime}$ & $104^{\circ} 14.17^{\prime}$ & 945 & 2 \\
\hline HUG & $04^{\circ} 55.98^{\prime}$ & $104^{\circ} 12.43^{\prime}$ & 1010 & 3 \\
\hline SIN & $05^{\circ} 03.60^{\prime}$ & $104^{\circ} 03.90^{\prime}$ & 1000 & 3 \\
\hline TMR & $05^{\circ} 18.07^{\prime}$ & $104^{\circ} 02.32^{\prime}$ & 60 & 4 \\
\hline BRT & $05^{\circ} 08.41^{\prime}$ & $104^{\circ} 17.10^{\prime}$ & 795 & 4 \\
\hline \multicolumn{2}{|c|}{ Velocity, $\mathrm{km} / \mathrm{s}$} & & \multicolumn{2}{|c|}{ Depth, km } \\
\hline \multicolumn{2}{|c|}{3.0} & & \multicolumn{2}{|l|}{0} \\
\hline \multicolumn{2}{|c|}{5.6} & & \multicolumn{2}{|l|}{1} \\
\hline \multicolumn{2}{|c|}{6.6} & & \multicolumn{2}{|l|}{19} \\
\hline \multicolumn{2}{|c|}{7.9} & & \multicolumn{2}{|l|}{33} \\
\hline
\end{tabular}

better than 0.1 and $0.2 s$ for $P$ and $S$ waves, respectively, using WWV signals for clock corrections every two days.

\section{Data Processing and Selection}

\section{Hypocentre Location Procedure and Vp/Vs Ratio}

Aftershocks were located using HYPOINVERSE [Klein, 1978] modified for station elevation corrections along ray paths. Standard errors on hypocentre locations generally underestimate the true errors on absolute locations; nevertheless, they are good indicators of the quality of locations in our network configuration [Lyon-Caen et al., 1988]. More than 1000 aftershocks were recorded during the survey. The following criteria were used to select the March events: rms $<0.4 \mathrm{~s}$, erh $<3 \mathrm{~km}$, erz $<5 \mathrm{~km}$, at least $4 \mathrm{P}$-and $2 \mathrm{~S}$-readings, and a distance to the closest station smaller than depth $D$, except for shallow events $(D<5 \mathrm{~km})$ for which the closest station was required to be at a distance less than $10 \mathrm{~km}$. For February events, these criteria were about 5 times less selective. As depth determination is highly sensitive to the choice of $\mathrm{Vp} / \mathrm{Vs}$ ratio, we have selected the best 50 events to determine a $\mathrm{Vp} / \mathrm{Vs}$ of $1.65 \pm 0.01$. Relocating aftershocks using values ranging from 1.60 to 1.73 yielded to the same $\mathrm{Vp} / \mathrm{Vs}$ ratio within the standard deviation found according to a rms minimum analysis.

\section{Velocity structure and computational procedure}

No detailed information on the velocity structure below the Liwa area is available. We thus use the 114 best-recorded aftershocks (rms $<0.25 \mathrm{~s}$ ) from the March period as a representative sample of all aftershocks. They are successively located in a half-space with a P-velocity ranging from 2.5 to $8.5 \mathrm{~km} / \mathrm{s}$. The mean rms shows a clear minimum near $5.0-5.5 \mathrm{~km} / \mathrm{s}$ for all events. We then use three subsets of events to find a velocity model for the upper crust, following the procedure described in Déverchere et al. [1993]. These tests were performed using an initial simple crustal model for which interface depths and velocities are subsequently changed, based on previous models deduced from refraction and seismicity studies in Sumatra [Kieckhefer et al., 1980] and Sunda Strait [Harjono et al., 1991]. The velocity structure finally selected (Table) yields a smaller mean rms at all depths than any of the previous half- 
space models. This is partly due to the larger number of parameters involved; however, it probably also reflects the better adequacy of such a velocity structure in locating shallow events compared to a half-space structure. The 114 events are successively located with initial depth values spaced every 5 $\mathrm{km}$ (from 5 to $25 \mathrm{~km}$ ) in order to identify and discard instable hypocentres. We separate the relocation process of the aftershocks using two different weighting schemes: for February and March periods, phases are downweighted from distances of 50 to $1000 \mathrm{~km}$, and from 50 to $300 \mathrm{~km}$, respectively. Finally, S-phases have a $50 \%$ weighting compared to P-phases.

\section{Aftershock Distribution, Fault Plane Solutions, and Stress Tensor}

After selecting stable solutions using the parameters determined above, we finally kept 110 and 345 aftershocks recorded before and after March 1, 1994, respectively (Figure 2). Large errors affect the February locations because of the low density of the network. In March, aftershocks display an average rms of $0.25 \mathrm{~s}$, and reach depths of $30 \mathrm{~km}$. Their magnitudes range from 0.0 to 3.0. Hypocentres inside the network have an estimated horizontal and vertical accuracy of $2 \mathrm{~km}$ and $4 \mathrm{~km}$, respectively, for this March period.
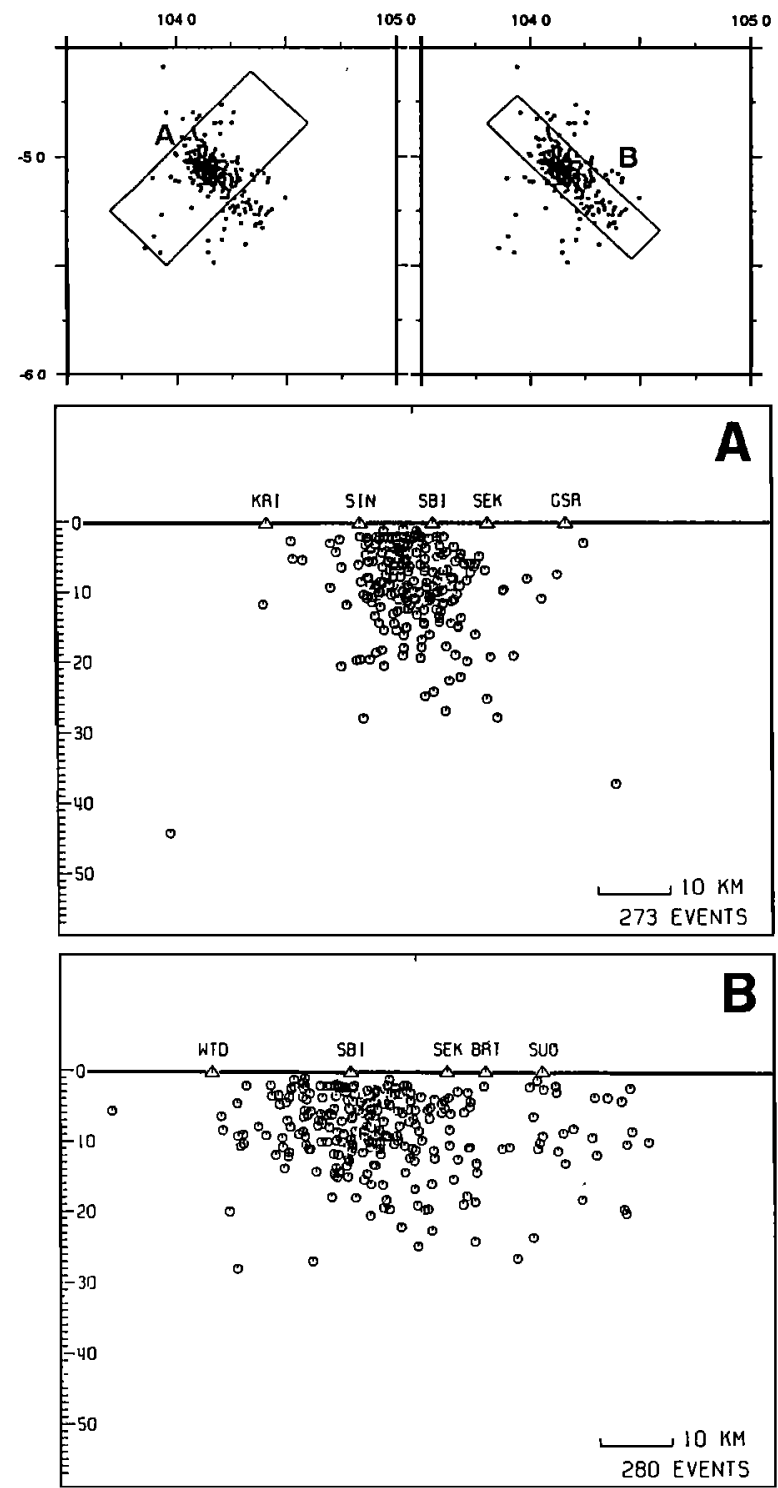

Figure 3. Cross sections perpendicular (A) and parallel (B) to the main active fault system (GSF). Only March aftershocks (345 events located by the local portable array) are plotted. Triangles are seismic stations. No vertical exaggeration.

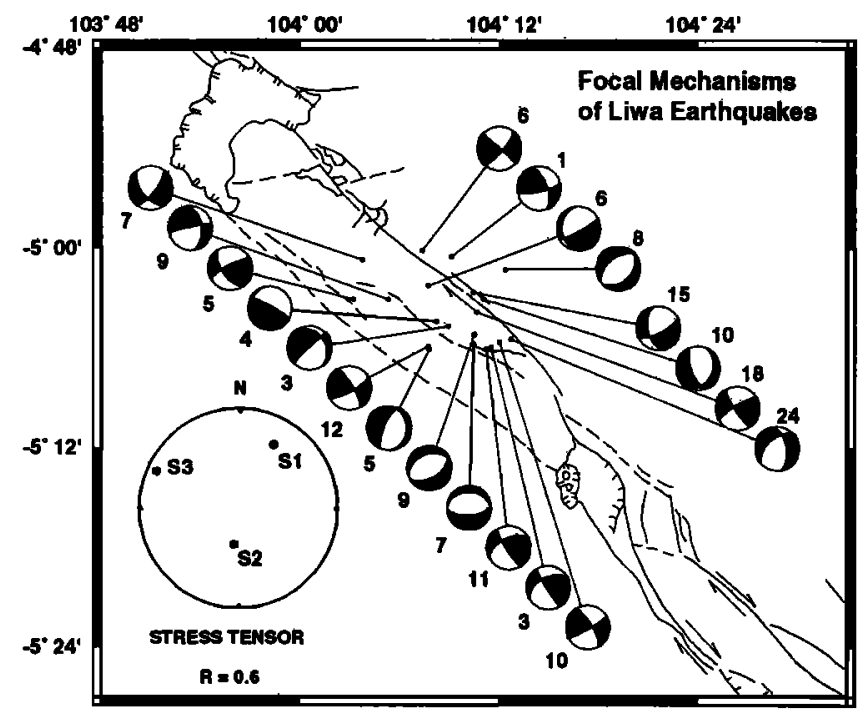

Figure 4. Fault plane solutions determined, and computed stress axis directions (lower left corner). The shape ratio of the stress tensor is $R=\left(\sigma_{2}-\sigma_{1}\right) /\left(\sigma_{3}-\sigma_{1}\right)$. Number close to each beachball is depth of event. Lines: same legend as Figure 2.

Aftershocks are numerous from $104^{\circ} \mathrm{E}(15 \mathrm{~km}$ SE of Ranau lake) up to the Suwoh volcanic area (i.e. along $30 \mathrm{~km}$ ) and extend laterally over $15-20 \mathrm{~km}$ (Figure 2). Although less well resolved because of the less dense network in the southernmost part of the studied area, weaker, but significant activity, is nonetheless detected southeast of Suwoh up to the Semangka fault (Figure 2). The Suwoh area appears to be a relatively quiet zone during the recording period (Figures 2 and 3 ), with nearly all aftershocks occurring inside the old pull-apart. On a cross section perpendicular to the Ranau-Suwoh fault (Figure 3A), aftershocks are concentrated within a width of 15 $\mathrm{km}$ and a depth of $18 \mathrm{~km}$ under sites SIN and SBI. A cross section parallel to the GSF (Figure 3B) shows two groups of events (from WTD to BRT, and SE of SUO) reaching depths of $25 \mathrm{~km}$, with a maximum around $10 \mathrm{~km}$. Between them, there is a well-defined $8 \mathrm{~km}$ gap in the aftershocks, near BRT and SUO.

We use P-wave first motions recorded on the whole network to construct individual fault plane solutions for events with at least 6 polarities and 270 degrees of azimuthal coverage. In addition, we have checked that computed take-off angles correspond to observed P-wave paths (direct or refracted). Twenty events meet these criteria and provide quite reliable solutions (Figure 4). They are used to deduce a stress tensor solution following the inversion method of Carey-Gailhardis and Mercier [1987]. Among 20 solutions, 19 are correctly superimposed in a right dihedra analysis, and lead to maximum and minimum horizontal stress axes $\sigma_{1}$ and $\sigma_{3}$ striking $\mathrm{N} 30^{\circ} \mathrm{E}$ and $\mathrm{N} 294^{\circ} \mathrm{E}$, respectively, revealing a strike-slip regime (Figure 4 ). If we compare the $\sigma_{3}$ azimuth to the one found in the Sunda strait [Harjono et al., 1993], we may assume a smooth and progressive transition of the stretching direction from $E-W$ in the Sunda strait to NW-SE in the Sumatra island.

\section{Discussion and conclusions}

\section{The mainshock}

When comparing the PDE position of the mainshock relative to the aftershock distribution, we note an eastward shift of about $20 \mathrm{~km}$ (Figure 1), like most of the other teleseismic determinations (see above). It should be noted that the location of a magnitude 5 event constrained by an OBS network off South Sumatra in 1991 was similarly shifted $48 \mathrm{~km}$ northeast [Zen Jr., 1993]. Consequently, we infer that the absolute locations displayed on Figure 1 are systematically biaised 20 to $50 \mathrm{~km}$ westwards, presumably due to the anomalous propagation effects commonly occurring near subduction 
zones [e.g., Katsumata et al., 1994]. Among the hypocentres and focal solutions of the 1994 mainshock, we prefer the centroid location (CMT-Harvard) at $5.15^{\circ} \mathrm{S}, 104.27^{\circ} \mathrm{E}, 16 \mathrm{~km}$ depth, and the Moment Tensor solution [Seismological Notes, 1994], because of its consistency with the active GSF surface expression and dip (Figure 2).

\section{Stresses and regional kinematics}

As suggested by the aftershock distribution described above and the lack of coseismic rupture at the surface [Duquesnoy el al., this issue], the 20 focal mechanisms determined provide evidence for various post-seismic stress adjustments on secondary faults located in the Ranau-Suwoh paleo-pull-apart depression, which were triggered by the main right-lateral strike-slip motion along the Ranau-Suwoh active fault segment (Figure 3). Therefore, the structural inheritance, in this case the paleo-pull apart, controls the aftershock distribution and explains its breadth. Concerning stresses, we note the smooth change of the $\sigma_{3}$ azimuth which tends to parallel the GSF, when going from the Sunda strait up to the inner Sumatra island. Furthermore, the direction of the $\sigma_{1}$ axis $\left(\mathrm{N} 29^{\circ} \mathrm{E}\right)$ is consistent with the slip vector azimuth $\left(\mathrm{N} 20^{\circ} \mathrm{E}-\mathrm{N} 30^{\circ} \mathrm{E}\right)$ deduced from thrust earthquakes at about $6^{\circ} \mathrm{S}$ and $103^{\circ} \mathrm{E}$, whereas the latter strikes nearly N-S in the Sunda strait [McCaffrey, 1991]. This seems to be the direct effect of the increasing obliquity of the plate convergence westward from the Sunda strait.

\section{Rupture process and effect of volcanism}

We observe that, contrary to 1933 , the rupture did not reach the Ranau lake caldera, which is an old pull-apart resulting from a releasing right-stepover [Bellier and Sébrier, 1994]. The volcanic area of Suwoh has a similar origin, but is a smaller and complex pull-apart basin which could act as a failed asperity. It is worth noting that the strongest aftershocks mainly appeared in the southern segment during February, and then tended to migrate northwestwards (Figure 2). The dimensions of the rupture area inferred from map view and depth distribution of aftershocks (about 55 by $20 \mathrm{~km}$ and from 0 to $25 \mathrm{~km}$ depth, Figures 2 and 3) fit well with the seismic energy released. Aftershocks were located as deep as $28 \mathrm{~km}$ (Figure 3). Thus, the seismogenic thickness of the crust is large, although the GSF is located on the Sumatra magmatic arc. A seismic gap is found beneath the active volcanic zone of Suwoh. We conclude that, as far as rigidity of the crust is concerned, the weakening effect of volcanism is limited in space. Thus it appears that volcanoes act as plumes without large lateral heat diffusion, and that the volcanic, thermal, and structural context strongly controls the rupture process and the seismic moment release along the GSF system.

Acknowledgments. We are very grateful to all who helped us on the field, and especially to people and institutions from Liwa district. Thanks are also due to those who have participated to the preparation of the field experiment in France and Indonesia. We benefited from the assistance of BMG and GRDC. The efficiency of the 'Service Scientifique' (French Embassy in Jakarta) was appreciated. Special thanks are due to Dr. S. Pramumijoyo, Ir. Suparka, Pr. M.T. Zen, and other colleagues from Geoteknology-LIPI for their invaluable support and guidance during this work. Field expedition was supported by the French Ministry of Environment ('Délégation aux Risques Majeurs'). ORSTOM and LIPI provided support in data processing. 'Géosciences Azur' contribution 50, and IPGP contribution 1438.

\section{References}

Bellier, $O$. and M. Sébrier, Relationship between tectonism and volcanism along the Great Sumatran Fault Zone deduced by SPOT image analyzes, Tectonophysics, 233, 215-231, 1994.

Bellier, $O$. and $M$. Sébrier, Is the slip rate variation on the Great
Sumatran Fault acommodated by fore-arc stretching?, Geophys. Res. Lett., 22, 1969-1972, 1995.

Berlage, H.P., De aardbeving in Zuid Sumatra van 25 juni 1933 , waarnemingen in het epicentrale gebied, Nat. Tijdschr. $v$. Ned. Ind., 94, 15-36, 1934.

Carey-Gailhardis, E., and J.L. Mercier, A numerical method for determining the state of stress using focal mechanisms of earthquake populations: Application to Tibetan teleseisms and microseismicity of Southern Peru, Earth Planet. Sci. Lett., 82, 165-179, 1987.

Déverchère, J., F. Houdry, N.V. Solonenko, A.V. Solonenko, and V.A. Sankov, Seismicity, active faults and stress field of the North Muya region, Baikal rift: New insights on the rheology of extended continental lithosphere, J. Geophys. Res., 98, 19,895-19,912, 1993.

Diament, M., H. Harjono, K. Karta, C. Deplus, D. Dahrin, M.T. Zen, Jr., M. Gérard, O. Lassal, A. Martin, and J. Malod, Mentawai fault zone off Sumatra: A new key to the geodynamics of western Indonesia, Geology, 20, 259-262, 1992.

Duquesnoy, Th., O. Bellier, M. Kasser, M. Sébrier, Ch. Vigny, and I. Bahar, Pre- and post-seismic deformation associated to the 1994 Liwa earthquake derived from geodetic measurements, Geophys. Res. Lett., this issue.

Fitch, T.J., Plate convergence, transcurrent faults, and internal deformation adjacent to Southeast Asia and western Pacific, J. Geophys. Res., 77, 4432-4460, 1972.

Harjono, H., M. Diament, J. Dubois, M. Larue, and M.T. Zen, Seismicity of the Sunda Strait: Evidence for crustal extension and volcanological implications, Tectonics, 10, 17-30, 1991.

Harjono, H, M. Sébrier, and M. Diament, Correction and addition to "Seismicity of the Sunda Strait: Evidence for crustal extension and volcanological implications" by H. Harjono, M. Diament, J. Dubois, M. Larue, and M.T. Zen, Tectonics, 12, 787-790, 1993.

Katili, J.A. and F. Hehuwat, On the occurrence of large transcurrent faults in Sumatra, Indonesia, J. Geosci. Osaka City Univ., 10, 5-17, 1967.

Katsumata, K., M. Ichiyanagi, M. Miwa, and M. Kasahara, Aftershock distribution of the October 4, $1994 \mathrm{Mw} 8.3$ Kurile islands earthquake determined by a local seismic network in Hokkaido, Japan, Geophys. Res. Lett., 22, 1321-1324, 1995.

Kieckhefer, R.M., G.G. Shor, Jr., J.R. Curray, W. Sugiarta, and F. Hehuwat, Seismic refraction studies of the Sunda trench and fore arc basin, J. Geophys. Res., 85, 863-889, 1980.

Klein, F.W., Hypocenter location program HYPOINVERSE, Part 1, User's guide to versions 1, 2, 3, and 4, U.S. Geol. Survey Open File Rep. 78-694, 1978.

Lyon-Caen, H., and 10 others, The 1986 Kalamata (South Peloponnesus) earthquake: Detailed study of a normal fault, evidences for East-West extension in the Hellenic arc, J. Geophys. Res., 93, 14,967-15,000, 1988.

McCaffrey, R., Slip vectors and stretching of the Sumatran fore-arc, Geology, 19, 881-884, 1991.

Mount, V.S., and J. Suppe, Present-day stress orientations adjacent to active strike-slip faults: California and Sumatra, J. Geophys. Res., 97, 11,995-12,013, 1992.

Newcomb, K.R. and W.R. McCann, Seismic history and seismotectonics of the Sunda arc, J. Geophys. Res., 92, 421-439, 1987.

Seismological Notes, Bull. Seism. Soc. Am., 84, $2023,1994$.

Zen Jr., M.T., Déformation de l'avant-arc en réponse à une subduction à convergence oblique. Exemple de Sumatra, Ph.D. Thesis, 253 pp. Paris VII Univ., 1993.

J. Déverchère, UMR Géosciences Azur, EP 125, Observatoire Océanologique, Université Pierre et Marie Curie, BP 48, 06230 Villefranche-sur-Mer, France. (e-mail: jack@ccrv.obs-vlfr.fr)

M. Diament and Rémy Louat, Laboratoire de Gravimétrie et Géodynamique (J.E. 335), Institut de Physique du Globe, 4 Place Jussieu, 75252 Paris, France. (e-mail: diament @ipgp.jussieu.fr)

H. Harjono, D. Hidayat and C. Widiwijayanti, Puslitbang Geoteknologi LIPI, Jl Cisitu, Bandung 40135, Indonesia. (e-mail: tina@geotek.lipi.go.id)

M. Sébrier, URA-CNRS Géophysique et Géodynamique interne, Université de Paris-Sud, B. 509, 91405 Orsay Cédex, France.

(Received March 15, 1996; revised June 18, 1996; accepted June 22, 1996.) 